\title{
Flora Near and Far: Accumulating Knowledge on Plants in Eighteenth-Century Zurich
}

\author{
Meike Knittel
}

In 1740, while preparing the publication of his Enumeratio methodica stirpium Helvetiae indigenarum, which became the first comprehensive flora of Switzerland, Albrecht von Haller (1708-1777) wrote from Göttingen to his friend Johannes Gessner (1709-1790) in Zurich asking a favour. Knowing that Gessner had catalogued the "loca natalia" of many rare Swiss plants based on his in-depth first-hand knowledge, Haller wished to receive an excerpt of this record. ${ }^{1}$ At the same time, Gessner himself was interested in plants from all over the world, as he was working on a universal history of plants ("historia plantarum"), intending to cover all aspects including localities, cultivation and uses, especially medical and economic ones. ${ }^{2}$ Most importantly, Gessner planned to include illustrations of the characteristics needed to classify a plant according to the Linnaean classification system, which was becoming increasingly popular in those years. ${ }^{3}$ To Gessner, this classification system seemed a good way to engage a large number of people in the creation of plant knowledge. Illustrations, he hoped, would facilitate access to Linnaean taxonomy

1 Letter, A. von Haller to J. Gessner, 10 June 1740. Henry E. Sigerist, Albrecht von Haller's Briefe an Johannes Gesner (1728-1777), Abhandlungen der Gesellschaft der Wissenschaften 11 (Berlin: Weidmann, 1923), 146.

2 Autobiography J. Gessner, Zentralbibliothek Zürich, zBz, Hss., Ms. M 18.10, Urs Boschung, Johannes Gessner (1709-1790): Der Gründer der Naturforschenden Gesellschaft in Zürich; Seine Autobiographie - aus seinem Briefwechsel mit Albrecht von Haller; Ein Beitrag zur Geschichte der Naturwissenschaften in Zürich im 18. Jahrhundert (Alpnach-Dorf: KOPRINT AG, 1995), 44.

3 On the increasing popularity of the Linnaean system, or the resistance to it respectively, in different locations, see Miguel A. Puig-Samper, "Difusión e institucionalización del sistema linneano en España y América," in Mundializacion de la ciencia y cultura nacional: Actas del congreso international "Ciencia, Descubrimento y Mundo Colonial," ed. Antonio Lafuente, Alberto Elena and María Luísa Ortega (Aranjuez: Doce Calles, 1993); Marco Beretta and Alessandro Tosi, ed., Linnaeus in Italy: The Spread of a Revolution in Science, (Sagamore Beach: Science History Publications, 2007); Andreas Önnerfors, "Auswärtige Saamen und Gewächse ingleichen zur Correspondence: Die Verbreitung Linnéscher Naturalhistorie in Schwedisch-Pommern im 18. Jahrhundert," in Wissen im Netz: Botanik und Pflanzentransfer in europäischen Korrespondenznetzen des 18. Jahrhunderts, ed. Regina Dauser et al. (Berlin: Akademie-Verlag, 2008). 
and thereby recruit more and more people to help compile a complete record of the world's flora.

A few years later, Gessner commissioned the miniaturist Christian Gottlieb Geissler (1729-1814) to draw and engrave more than a thousand plants growing in Europe, Asia, Africa, and the Americas, for the purpose of illustrating fructification organs. The resulting plates were published posthumously, at the turn of the century, by Gessner's grandnephew Christoph Salomon Schinz (1764-1847) under the title Tabulae phytographicae. ${ }^{4}$ The Tabulae phytographicae provided information on the habitat of many of the plants depicted. ${ }^{5}$ In other words, they linked the particular species to a geographical place or an environmental setting. However, far from being standardised, these indications referred differently to different territories. Localities range from references to entire continents - such as "Africa" (often meaning South Africa) or "Asia," differentiating between "northern" and "southern" only for Europe and the Americas - over larger regions, to countries. Countries in Europe, for instance, included France ("Gallia"), Italy ("Italia"), Spain ("Hispania"), and of course Switzerland ("Helvetia"); Asian territories included Malabar, Ceylon, and India. ${ }^{6}$

The great variability of this habitat information given by the Zurich naturalist raises the question of perception of the plant world. More precisely: How did an 18th-century botanist understand and map the abundance of plant species he came to know? What did he know about the territories mentioned as habitats? This particular case is of interest because European naturalists like Gessner crucially contributed to the universalisation of plant knowledge

4 Johannis Gessneri Tabulae phytographicae, analysin generum plantarum exhibentes / cum commentatione edidit Christ. Sal. Schinz, Zurich, 1795-1804. Although the Tabulae phytographicae were published only posthumously, they circulated in advance. Gessner showed them to visitors in Zurich and sent tableaus IV, XIII, XLIV and XLIX to some of his correspondents. Albrecht von Haller, Carl Linnaeus, Jean-François Séguier and Abraham Gagnebin verifiably received printings during the 175 os and 176 os and were asked to evaluate them. On Gagnebin's use of the illustrations in his botanical study, see Rossella Baldi, "La circulation du savoir botanique par le texte et par l'image: Le Species plantarum d'Abraham Gagnebin," in Rosseau Botaniste:Je vais devenir plante moi-même, ed. Claire Jaquier and Timothée Léchot (Fleurier: Editions du Belvédère, 2012).

5 Information on the origins and growing conditions was of no importance to the classification of plants according to the Linnaean system, which organised species based on artificial criteria, according to external features. The Tabulae phytographicae contain only annotations of localities for the first thirty tableaus.

6 Tableau XIII, depicting representatives of the fifth Linnaean class, for example, shows species occurring "in Europe, Asia and Northern America" ("Habitat in Europae, Asiae, Americae septentrionalibus") as well as in Southern Europe ("in Europa australi"). Tabulae phytographicae, 102 and 107. 


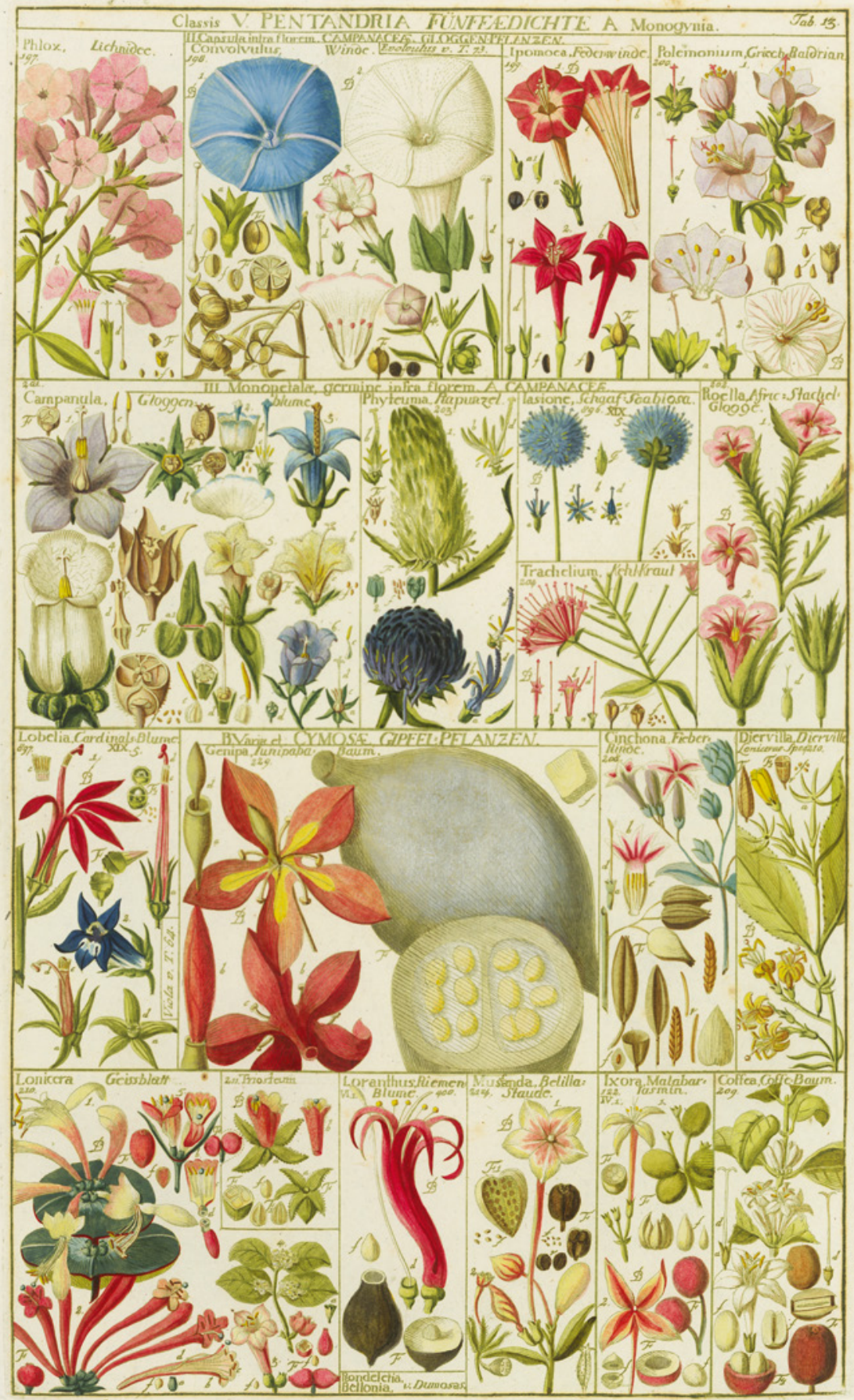

FIGURE 4.1 Tab. XIII of Gessner's Tabulae phytographicae depicting representatives of the fifth Linnaean class. Zentralbibliothek Zürich, Alte Drucke, NF 170 
and the perception of distant political territories. Therefore, it is important to understand the factors influencing what he knew about the flora of the different regions of the world. Starting from the localities printed alongside the plant engravings within Tabulae phytographicae, this paper examines the Zurich botanist's knowledge of plants from far-away territories using the auction catalogue of Gessner's library and the herbarium he put together for the Zurich Physical Society, of which he was co-founder and an active member from 1746 until his death. ${ }^{7}$

The eighteenth century saw numerous expeditions supported by European trading companies and colonial administrations, aimed at gaining access to potentially useful plants from Asia, the Americas, and the islands in the South Seas. The journeys not only generated many records on these distant worlds, but also brought a plethora of plant seeds and dried specimens into the botanical gardens and herbariums of places like Madrid, Paris, and Kew. ${ }^{8}$ For a long time, research focused on transfers of botanical knowledge within the individual European colonial empires. ${ }^{9}$ While, in recent years, studies have shown that botanists collecting information and plant species regularly overcame imperial borders, little is currently known about what kind of knowledge of the flora from far-away regions reached the European hinterlands. ${ }^{10}$ The perception of plant knowledge outside Atlantic port cities, globally influential trading

$7 \quad$ Gessner's library is documented in manuscript and print, both surviving in the ZBZ. 1) Manuscript Department, Ms. Z II 620 (manuscript of the catalogue handed down in the estate of the first director of the Swiss National Museum, Heinrich Angst (1847-1922); 2) Rare Book Department, Dr O 456.4 (Johann Füssli \& Son, Catalogus Librorum Bibliothecae Joannis Gessneri [...], Zurich 1798), referred to as Catalogus in the following. The herbarium is preserved in the Department of Systematic and Evolutionary Botany of the University of Zurich under the title Hortus siccus Societatis Physicae Tigurinae, collectus et Linnaeana methodo dispositus a Joanne Gesnero, 1751. On the members and activities of this society, see Sarah Baumgartner, "Das nützliche Wissen: Akteure, Tätigkeiten, Kommunikationspraxis und Themen der Naturforschenden Gesellschaft in Zürich, 1746 bis ca. 1830" (PhD diss., University of Bern, 2019).

8 David Miller and Peter H. Reill, ed., Visions of Empire: Voyages, Botany and Representations of Nature (Cambridge: Cambridge University Press, 1996); Mauricio Nieto, "Presentación gráfica, desplazamiento y aprobación de la naturaleza en las expediciones botánicas del siglo XVIII," Asclepio 47, no. 2 (1995); Catherine Gaziello, L'expédition de Lapérouse 17851788: réplique française aux voyages de Cook (Paris: Cт HS, 1984).

$9 \quad$ For a study beyond European empires, see Yota Batsaki, Anatole Tchikine and Sarah Burke Cahalan, ed., The Botany of Empire in the Long Eighteenth Century, Dumbarton Oaks Symposia and Colloquia (Baltimore: Dumbarton Oaks Publishing, 2017).

10 For examples of 19th-century actors from Switzerland in an imperial context, see Bernhard C. Schär, Tropenliebe: Schweizer Naturforscher und niederländischer Imperialismus in Südostasien um 1900 (Frankfurt am Main: Campus Verlag, 2015); Andreas Zangger, Koloniale Schweiz: Ein Stück Globalgeschichte zwischen Europa und Südostasien (18601930) (Bielefeld: transcript, 2011). 
centres and university towns remains insufficiently understood.1 ${ }^{11}$ Therefore, this contribution investigates how different plant worlds were perceived in the context of a Swiss city that neither was directly involved in overseas trade nor had a university, but was the centre for the training of Protestant clergy. Looking through the lens of an 18th-century botanist from Zurich, namely Johannes Gessner, this paper asks how a researcher working a long way from the flora's origin perceived and organised the ever-expanding plant world.

To do so, this contribution first seeks to understand how the Zurich naturalist's expert knowledge on Swiss plants was formed. Then, using the example of American plants, we argue that Gessner's perception of extra-European floras was determined by the joint presence of publications in languages he understood and specimens from those regions. Finally, the case of a collection of dried plants from South Africa sheds light on what happened in the absence of factors that were compelling in previous cases.

\section{Knowing What Is Near}

Like many others of his generation, Gessner spent most of his life where he was born. He left Zurich, only, at the age of seventeen, to study medicine at the Universities of Basel and Leiden, as well as in Paris. These stays had a longterm influence on Gessner's botanical activities and thus affected which plant worlds he became acquainted with. As we shall see in more detail below, his decision to study in Leiden was particularly momentous as Leiden had been a centre of botanical study and cultivation of plants from all over the world since the intensified presence of Europeans in non-Europeans areas. ${ }^{12}$ The involvement of the Leiden townspeople in global trade meant that seeds were imported from Asia, South Africa, and the Americas in abundance to the Dutch town. As a result, botanists were able to gather detailed information on these "new" plants. During his studies there, Gessner visited the university garden as well as several private gardens, which cultivated and sold plants from every

11 An exception examining this question for an outstanding Swiss naturalist of the 16th century: Urs B. Leu, “Konrad Gessner und die Neue Welt," Gesnerus 49, no. 3-4 (1992).

12 On 16th-century botany in Leiden, see José Pardo-Tomás, "Two Glimpses of America from a Distance: Carolus Clusius and Nicolás Monardes," in Carolus Clusius: Towards a Cultural History of a Renaissance Naturalist, ed. Florike Egmond, G. Hoftijzer and Robert W. Visser (Amsterdam: Koninklijke Nederlandse Akademie van Wetenschappen, 2007); Florike Egmond, Esther van Gelder and Nicolas Robin, eds., Flowers of Passion and Distinction: Practice, Expertise and Identity in Clusius' World (Stuttgarrt: Franz Steiner Verlag, 2012). For an overview, see William T. Stearn, "The Influence of Leyden on Botany in the Seventeenth and Eighteenth Century," The British Journal for the History of Science 1, no. 2 (1962). 
known corner of the world. ${ }^{13}$ His choice of Leiden was very typical of the time, since Herman Boerhaave (1668-1738) attracted botanically interested medical students from all over Europe. Yet, by studying in Leiden, Gessner did no more than follow a local tradition; indeed, young people from Zurich had been students at the Protestant university since the 17 th century. ${ }^{14}$

Having graduated as a medical doctor in Basel, Gessner returned to his hometown, where his family had had citizen status for more than two hundred years, and subsequently left the city only for short journeys. In Zurich, Gessner produced botanical illustrations of, and published dissertations on, the uses of local plants as well as plants growing in distant territories. ${ }^{15}$ In addition, together with his close friend Albrecht von Haller from Bern (then professor at the University of Göttingen), Gessner pursued the objective of compiling a comprehensive flora of Switzerland, a work eventually completed and published by Haller as Enumeratio in $1742 .{ }^{16}$ His expert knowledge of Swiss plants also emerges in the indications of localities within the Tabulae phytographicae, especially in cases where Gessner informs the reader that a depicted specimen grew, for example, "on meadows" ("pratis"), "on crags" ("ad rupes") or "on fields" ("segetes") in Switzerland, thereby coming much closer to indications of habitat in a modern sense than with the statements given for non-European plants (see below). ${ }^{17}$ While Gessner largely followed the indications of habitat given by Linnaeus in his Species plantarum, for plants growing in Switzerland, his work provides further information (e.g. in the case of Campanula thyrsoides L. and Jasminum officinale L.) where he could add Switzerland or the Swiss Alps respectively as habitats. ${ }^{18}$

13 On the Zurich botanists' long-term relations to the merchant gardener Willem van Hazen, see Meike Knittel, "Netzwerke der Botanik: Johannes Gessner (1709-179o) und die botanische Forschung im 18. Jahrhundert” (PhD diss., University of Bern, 2018).

14 Sabine Heller, Boerhaaves Schweizer Studenten: Ein Beitrag zur Geschichte des Medizinstudiums (Zurich: Juris-Verlag, 1984). Hanspeter Marti, "Leiden," Historisches Lexikon der Schweiz Online, last modified November 20, 2008, https://hls-dhs-dss.ch/de/arti cles/oo6615/2008-11-20/ (accessed on 30 April 2020).

15 For an analysis of Gessner's dissertation on officinal plants see Meike Knittel, "Dominus creavit ex terra medicamenta': Heilpflanzenwissen in Johannes Gessners Phytographia sacra," in Wer das Gras wachsen hört: Wissensgeschichte(n) der pflanzlichen Ressourcen vom Mittelalter bis ins 20. Jahrhundert, ed. Simona Boscani Leoni and Martin Stuber, Jahrbuch für Geschichte des ländlichen Raumes 14 (Innsbruck: Studien-Verlag, 2017).

16 For details on the collaboration, see Boschung, Johannes Gessner.

17 Tabulae phytographicae, 22; 44; 92.

18 Carl Linnaeus, Species plantarum: exhibentes plantas rite cognitas, ad genera relatas, cum differentiis specificis, nominibus trivialibus, synonymis selectis, locis natalibus, secundum systema sexuale digestas, (Holmiae: Impensis Laurentii Salvii, 1753), 167; Tabulae phytographicae, 103; Species plantarum, 7; Tabulae phytographicae, 7 . 
The Zurich naturalist had studied the Swiss flora for many decades. Travelling around the Swiss cantons, their subject and neighbouring territories, Gessner acquired extensive knowledge about the plants of what is today Switzerland. During his tour with Haller in 1728 alone, he studied the flora growing in the territory of Basel, around the cities of Biel, Neuchâtel, Lausanne, and Geneva. In the course of this study trip, he also explored the Alpine flora while crossing the passes in the Pennine, Bernese and Uri Alps. ${ }^{19}$ For years before and after, Gessner collected plants in the mountains of Appenzell, and again in Central Switzerland as well as in the territory of the Three Leagues. ${ }^{20}$ In the following decades as he was no longer able or in need to travel himself, he provided students from Zurich with funds to travel, so that they would bring him fresh plant material from these Alpine regions. ${ }^{21}$ Accumulating, in Zurich, plants from the Swiss mountains and sharing them with his correspondents in other places made Gessner a reputable specialist in Alpine botany.

With his focus on Alpine plants, the Zurich naturalist follows a local research tradition whose most prominent representative was his teacher Johann Jakob Scheuchzer (1672-1733). ${ }^{22}$ Besides being inspired by Scheuchzer's work, Gessner could also draw on plant material he had received from him as a gift, as the various comments in his herbarium indicate. ${ }^{23}$ Early on, Gessner could

19 Christoph Salomon Schinz, Preface to the Tabulae phytographicae, VII.

20 Autobiography J. Gessner, zbz, Hss., Ms. M 18.10, Boschung, Johannes Gessner, 24-45.

21 On the students' tours on Gessner's commission, see Meike Knittel and Reto Nyffeler, "Flora Alpina," in Montan-Welten: Alpengeschichte abseits des Pfades, ed. Tina Asmussen, Æther o3 (Zürich: intercom Verlag, 2019), last modified May 2019, https://aether.ethz.ch/ ausgabe/montan-welten/flora-alpina/, accessed on 26 April 2021; Meike Knittel, "Devenir botaniste au XVIII ${ }^{e}$ siècle: les premiers voyages de Gessner et des jeunes Zurichois dans les Alpes," Bulletin de l'Association culturelle pour le voyage en Suisse 20 (2019). On the relevance of exploration trips for scholarly careers, see Hanna Hodacs, "Linnaean Scholars Out of Doors: So Much to Name, Learn and Profit From," in Naturalists in the Field: Collecting, Recording and Preserving the Natural World from the Fifteenth to the Twenty-First Century, ed. Arthur MacGregor (Leiden: Brill, 2018).

22 The same holds true for Gessner's specialisation in grasses, becoming apparent in the indications for the plants depicted in tableau $\mathrm{v}$, which locates species in marshy areas or stagnant waters, for example. His interest presumably was inspired by the research of Johann Scheuchzer (1684-1738), another Zurich naturalist of the previous generation. On Johann Jakob Scheuchzer, see Simona Boscani Leoni, "Men of Exchange: Creation and Circulation of Knowledge in the Swiss Republics of the Eighteenth Century," in Scholars in Action: The Practice of Knowledge and the Figure of the Savant in the 18th Century, ed. André Holenstein, Hubert Steinke, and Martin Stuber (Leiden: Brill, 2013).

23 "HB Scheuchzer" is among others noted next to a Veronica species in vol. 1 of the Hortus siccus. Gessner also adopted Scheuchzer's practices, especially the annotation of a specimen's origin. For Scheuchzer's practices see Urs B. Leu, ed., Natura Sacra: Der Frühaufklärer Johann Jakob Scheuchzer (1672-1733) (Zug: Achius Verlag, 2012). 
study the collection of dried plants his teacher had put together in Zurich and continued to do so through Scheuchzer's heirs after his death. ${ }^{24}$

However, Gessner's interest was in no way limited to plants growing in the Swiss mountains. He was also well-informed about species growing in the French and Italian Alps ("in alpibus Galliae, Helvetiae, Italiae, etc.") and the Austrian ones ("Austriacis"), the Pyrenees ("in Alpibus Helveticis, Pyrenaeis, Austriacis") as well as the mountains of Lapland ("in Alpibus Lapponicis"), as the comments in the Tabulae phytographicae make clear. ${ }^{25}$ Partly, this was the result of publications available (such as Linnaeus's); but Gessner also corresponded with other botanists interested in Alpine flora. His correspondents Jean-François Séguier (1703-1784) and Carlo Allioni (1728-1804), for example, were willing to share the specimens they had collected on Monte Baldo or in Piedmont respectively, in return for species from the Swiss Alps. ${ }^{26}$ Thereby, they helped each other to become experts on plants growing on mountains in different regions.

It comes as no great surprise that a decades-long study of plants in the immediate neighbourhood of his hometown and his constant access to fresh plant material from the Swiss mountains were a sound foundation for Gessner's detailed knowledge of the flora of Zurich, the Old Swiss Confederacy and the Alps. However, it also became clear that the question of what a natural scientist was particularly interested and knowledgeable in was shaped by his contacts - local ones and those he made during his stays abroad. Does this hold true for plants from other world regions, for which the process of gathering knowledge was much less straightforward?

\section{$2 \quad$ Understanding What Is Far}

Looking at American plants, it becomes obvious that Gessner's perspective was influenced by him being a German-speaking protestant, as demonstrated by the publications he owned on Central and Southern America. These included, for example, the account of the Dominican Bartolomé de las Casas

24 On Gessner's access to Scheuchzer's collection, see also: Luc Lienhard, "La Machine Botanique': Zur Entstehung von Hallers Flora der Schweiz," in Hallers Netz: Ein europäischer Gelehrtenbriefwechsel zur Zeit der Aufklärung, ed. Martin Stuber, Stefan Hächler, and Luc Lienhard (Basel: Schwabe, 2005).

25 Tabulae phytographicae, 17, 31, 55 .

26 For Haller via Gessner: Letter, J.-F. Séguier to J. Gessner, 21 March 1751. Zbz, Hss., Ms. M 18.25.3. For Carlo Allioni's collecting activities: Letter, J.-F. Séguier to J. Gessner, 24 January 1751. ZBZ, Hss., Ms. M 18.25.2. 
(1484/85-1566) on the conquest of the "Indian countries" (Beschreibung der Indianischen Länder, 1665) in a German version, which evinced strong criticism of the Catholic Spanish colonial power. Besides, he owned the travelogue of New Spain by another cleric, Thomas Gage (c. 1603-1656), who had converted to Protestantism. ${ }^{27}$ The language of the publications available was key for the perception of plant knowledge. Gessner actively used German and Latin for his writing and, in addition, was able to understand French texts like Charles Plumier's (1646-1704) illustrated Description des plantes de l'Amérique and Louis Feuillée's (166o-1732) work on medical plants of Peru and Chile. ${ }^{28}$ However, within the library, the French publications are clearly outnumbered by Latin and German ones. Of the texts in Gessner's native language, many had originally been published in English, like the above-mentioned account of New Spain. Beyond that, German translations of Philip Miller's Gardener's Dictionary and Humphry Marshall's The American Grove enabled the Zurich naturalist to acquire knowledge on the cultivation of foreign species as well as on trees and shrubs native to North America. ${ }^{29}$ However, it was his command of Latin that enabled Gessner to explore new plant worlds, allowing him to access botanical knowledge published in London and Saint Petersburg as well as in various Swiss, Italian, German, French, and Dutch cities. In particular, the multitude of Latin books published in Leiden acquainted the Zurich naturalist with the variety of species growing not only in the Dutch city itself, but in botanical gardens elsewhere, for example in Montpellier. ${ }^{30}$ Consulting all the indices and treatises written in Latin, Gessner learned about the flora of Sweden as well as that of the East and West Indies.

Judging from the indications of habitats given for American plants in the Tabulae phytographicae Gessner's knowledge of the continent's flora seems considerably nuanced. Among others, they refer to political territories such as Brazil (then a Portuguese colony), Jamaica (under British rule), Mexico (an administrative unit in the Spanish Viceroyalty of New Spain) as well as the British colonies of Virginia and of Carolina (a collective term for North and

27 Catalogus, ZBz, Dr O 456.4, 123.

28 Catalogus, ZBz, Dr O 456.4, 38 and 42.

29 The German translation of Humphry Marshall's (1722-1801) work by Christian Friedrich Hoffmann (1762-1820) was published in 1788 under the title: Beschreibung der wildwachsenden Bäume und Staudengewächse in den vereinigten Staaten von Nordamerika. Catalogus, zBz, Dr O 456.4, 53 .

30 Gessner owned several descriptions of Leiden's botanical garden: Paul Hermann, Horti academici Lugduno-Batavi Catalogus (Lugduni Batavorum: Apud Cornelium Boutesteyn, 1687) and his Paradisus batavus in two editions. As well as: Herman Boerhaave's records from 1710 and 1720 and Adriaan van Royen, Flora Leidensis (Lugduni Batavorum: Apud Samuelem Luchtmans,1740). 
South Carolina). ${ }^{31}$ Some indications are even more specific, as in the case of the so-called "fever bark" (Cinchona officinalis), also shown in tableau XIII, known to be growing in Loja in [the Viceroyalty of] Peru ("Loxa Peruviae"). ${ }^{32}$

Such exact indications of habitats were facilitated by the strong interest of Gessner's contemporaries in the matter. ${ }^{33}$ Not only had he been able to read up about this species in a variety of publications, but he had also discussed the use of the plant against various diseases with other members of the Zurich Physical Society. The use of the plant as a remedy against fever and other afflictions was a subject of conversation in the Society's meetings, as its minutes and its published Abhandlungen (Transactions) show. ${ }^{34}$ Experiences with previously unknown plant species from the Americas, e.g. the Cinchona bark, fuelled expectations among Gessner's contemporaries that more and more plant riches could be expected from that part of the world..$^{35}$ Therefore, European botanical amateurs and professionals eagerly collected species and recorded information about plants from the Americas. The same holds true for passionflowers, for example: a coveted species among European botanists who tried to obtain dried specimens and seeds to grow. In the 1770s, the gardeners of the Physical Society succeeded in cultivating at least three different species of Passiflora in the Society's garden in Zurich: blue passionflower (Passiflora caerulea), Passiflora foetida with white flowers, and the yellow-flowering Passiflora lutea. ${ }^{36}$ Gessner had sixteen species of passionflowers engraved for his Tabulae phytographicae (fig. 4.2) and assembled a collection of passionflowers which

31 Tabulae phytographicae, for example for species on Tab. xxIx.

32 Tabulae phytographicae, 107.

33 For a study of the beliefs and practices around the "fever bark": Stefanie Gänger, $A$ Singular Remedy: Cinchona Across the Atlantic World, 1751-1820 (Cambridge, New York: Cambridge University Press, 2020).

34 The bark was discussed in two sessions, in August and September 176o. Tagbuch der Naturforschenden Gesellschaft, Staatsarchiv Zürich (StAZ), B IX 181, 50-6o. Many thanks to my colleague Sarah Baumgartner (Bern) for pointing me towards this source. The discussions within the meetings resulted in a publication in the Society's review: Johann Heinrich Rahn et al., "Bemerkungen von der Würkung der Fieberrinde in verschiedenen Krankheiten," Abhandlungen der Naturforschenden Gesellschaft in Zürich 1 (Zurich: Heidegger und Compagnie, 176o).

35 This is suggested by Johan Gustaf Hallman (1726-1795) in his account on passionflowers. Johan Gustaf Hallman, "Passiflora”, in Carl von Linné, Amoenitates Academicae 1 (Holmiae et Lipsiae: Apud Godofredum Kiesewette, 1749).

$3^{6}$ Anonymus [Salomon Schinz], Catalogus Horti Botanici Societatis Physicae Turicensis, Zurich 1776 . 


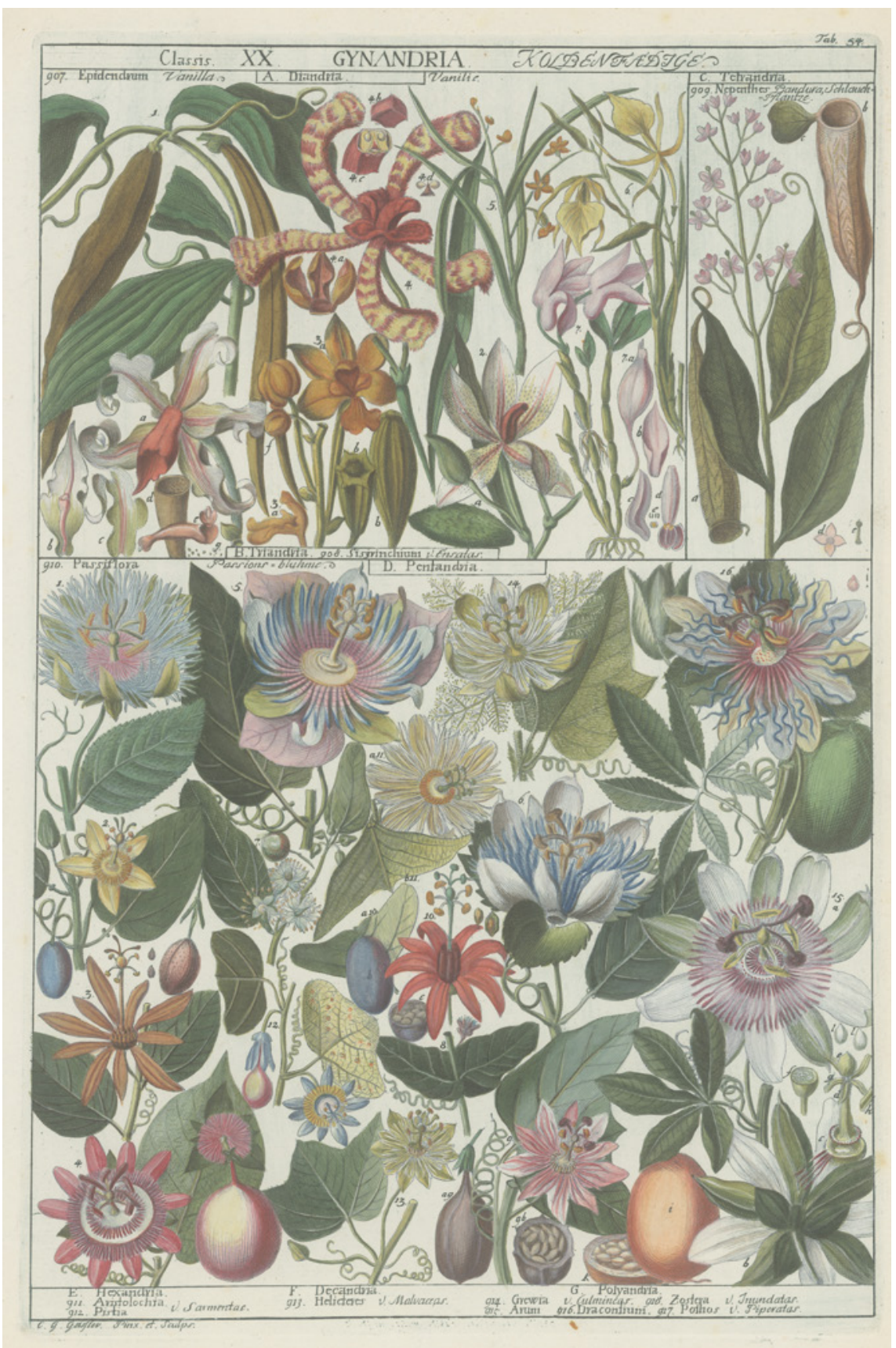

FIGURE 4.2 Tab. LIV of Gessner's Tabulae phytographicae showing passion flowers.

Zentralbibliothek Zürich, Alte Drucke, NF 170 
the German pharmacist Johann Gerhard Reinhard Andreae (1724-1793), visiting it in the early 1760 , considered remarkably extensive. ${ }^{37}$

Both plants, the Peruvian bark and the passionflowers, were the subject of dissertations published in the Amoenitates Academicae, a collective publication of dissertations by students of Linnaeus father and son. In this context, the Swedish botanist Hallman discussed the medical and economic uses of, as well as the religious and poetic interest in, passionflowers. In his account on the Passiflora, Hallman distinguished 22 species of the genus growing in North and South America. Gessner managed to acquire ten representatives of the genus until 1763 and added half a dozen in the following years, all of which he classified in volume 29 of the herbarium..$^{38}$ Because many others besides him were fascinated by passionflowers, Gessner could learn many details about the different species. Through Hallman's publication, he found out where exactly which species grew, whether in Virginia, Mexico, the Caribbean, Guyana, Peru or Brazil. ${ }^{39}$ Thus, knowledge on American plants landed in Zurich by a detour via Sweden.

The same can be said for knowledge on the flora of other territories. As Alix Cooper has pointed out, in the course of the eighteenth century, local flora went global. ${ }^{40}$ While the genre of the local flora originated in German university towns with botanical gardens in the seventeenth century, in the following decades, inventories were made for numerous territories all around the world. Gessner owned both - the older accounts published within the German Baroque context and those appearing throughout the eighteenth century especially those within in the Amoenitates Academicae. The dissertations of students at the University of Uppsala inventoried and discussed the flora of England, Palestine, Montpellier, and Denmark, of Kamchatka and the Cape of Good Hope. Moreover, they also recorded the plants growing in much smaller territories, i.e. private gardens like the garden of the Swedish merchant family Alströmer and the manor of Linnaeus's patron Carl Gustaf Tessin (1695-1770).41

37 Johann Gerhart Reinhart Andreae, Briefe aus der Schweiz nach Hannover geschrieben in dem Jare 1763, 2. Abdruck (Zurich, Winterthur: Heinrich Steiner und Comp. Buchhändlern, 1776), 64 .

38 Hortus siccus, vol. 29 "Gynandria", 79-95.

39 Hallman, Passiflora, 31. The Tabulae phytographicae do not give indications of localities for all plants depicted, although Gessner knew about them. This is the case for the passionflowers shown in plate LIV.

40 Alix Cooper, Inventing the Indigenous: Local Knowledge and Natural History in Early Modern Europe (Cambridge, New York: Cambridge University Press, 2007), 52.

41 Carl von Linné, Amoenitates Academicae. Catalogus, zBz, Dr O 456.4, 34. The different volumes of the Amoenitates Academicae appeared in Stockholm, and Erlangen and Leipzig respectively, from 1749 onwards. Gessner cited them regularly in all his publications. 
In addition, Gessner also received practical plant knowledge filtered through the Swedish lens. The German translation of the transactions of the Royal Swedish Academy of Sciences published in Leipzig gave him access to plant knowledge originally published in Swedish. From 1749 onwards, Abraham Gotthelf Kästner (1719-180o) made the Vetenskapsakademiens Handlingar (Transactions of the Royal Swedish Academy of Sciences) available for a German audience, because he was convinced that information was absorbed more easily when given in the reader's native language. At the same time, Kästner was in no doubt that knowledge produced in Sweden was useful beyond that country. ${ }^{42}$ Thanks to the German-language version, Gessner was able to learn about experiments with American trees and herbs in Sweden as well as the cultivation of exotic plants in Stockholm's botanical garden. ${ }^{43}$ The publication allowed him to gain an impression of growing conditions of foreign plants in Sweden and thus also enabled him to compare them to the situation in Zurich. Knowledge on plants like liquorice and melons thus became accessible for the Zurich naturalist through a combination of efforts by botanists and publishers in Sweden and Leipzig.

The local floras that figured within the Amoenitates Academicae were based on material that the students had themselves collected or others had sent to Linnaeus, for example the dissertation on the Surinamese plants based on the collection by Daniel Rolander (1723-1793) and Frédéric-Louis Allamand (1736-post 1803) - both assembled during their time in Dutch service. ${ }^{44}$ More

42 Abraham Gotthelf Kästner, Der Königl. Schwedischen Akademie der Wissenschaften neue Abhandlungen aus der Naturlehre, Haushaltungskunst und Mechanik; auf das Jahr 1741. Vol. 3 (Leipzig, Hamburg: Heinsius, 1750). On the transfers of the Handlingar see Ingemar Oscarsson, “'... who has had the courage and ambition to learn Swedish': The Handlingar of the Swedish Academy of Sciences in 18th Century European Translations, Adaptations, and Reviews," La Révolution française 13 (2018), accessed 20 April 2021, doi:10.400o/ lrf.1910.

43 Gessner took notice of: Mårten Triewald, "Anmerkungen über die Pflanzung ausländischer Frucht- und anderer Bäume in Schweden aus eigener Prüfung und Versuch vorgestellt von Martin Friedwald [sic!], Königl. Mechanico und Fortificationscapitain", in Der Königl. Schwedischen Akademie der Wissenschaften neue Abhandlungen aus der Naturlehre, Haushaltungskunst und Mechanik, auf das Jahr 1739 (Leipzig, Hamburg: Heinsius, 1749); Triewald, "Ein glücklich abgelaufener Versuch, ob die Glycyrrhiza oder das spanische Süßholz in Schweden wachse, und unsern Winter aushalten kann", in Der Königl. Schwedischen Akademie der Wissenschaften neue Abhandlungen aus der Naturlehre, Haushaltungskunst und Mechanik, auf das Jahr 1744, vol. 6 (Leipzig, Hamburg: Heinsius, 1751) as his notes preserved in manuscript prove: Repertorium. zBz, Hss., Ms. Z VIII 12.

44 David G. Frodin, Guide to Standard Floras of the World (Cambridge, New York: Cambridge University Press, 2001), 323. On Frédéric-Louis Allamand (1736-1809), a ship-surgeon from 
generally, when looking at the geographical coverage of these publications, it becomes obvious that most of the accounts on extra-European plants were based on collections carried out within the sphere of influence of the Dutch colonial trading companies. ${ }^{45}$

Such Dutch networks were effective in many ways. The numerous references to "Virginia" throughout the Tabulae phytographicae suggest that Gessner was intimately acquainted with the flora of this territory. On the one hand, he could refer to and rely on the Flora Virginica published in 1743 and 1762 , which in its second edition contained even a map of the area where John Clayton (1694/5-1773), pioneer of the English colony's flora, had botanised. ${ }^{46}$ Showing geographical features like mountains and watercourses, houses and trees, the map divides Virginia into smaller units. Numbers written alongside the rivers and bays provide information on the names of the significant geographical features and political entities ${ }^{47}$ However, Gessner's familiarity with plants from the English colony was not based solely on his reading of Flora Virginica. ${ }^{48}$ Instead, it was inspired by the plant material he had acquired from that region. The Zurich naturalist had a considerable number of dried specimens from Virginia in the herbarium, labelled "Claytono lecta in Virginia" and "Claytono ad Gronovium ex Virginia missa" referring to the Virginian specimens' journey from the Netherlands. ${ }^{49}$ This proves that Gessner stored plant

Vaud (then subject-territory of Bern), see Ernst Schlunegger, "Allamand, Frédéric-Louis," in Historisches Lexikon der Schweiz Online, last modified April 26, 2021, https://hls-dhs -dss.ch/de/articles/043932/2021-04-26/ (accessed on 30 April 2021). For a study of foreign surgeons in Dutch service, see Iris Bruijn, Ship's Surgeons of the Dutch East India Company: Commerce and the Progress of Medicine in the Eighteenth Century, (Leiden: Leiden University Press, 2009).

45 On the use of the Linnaean binomial nomenclature in colonial contexts: Staffan MüllerWille, "Walnuts at Hudson Bay, Coral Reefs in Gotland: The Colonialism of Linnean Botany," in Colonial Botany: Science, Commerce, and Politics in the Early Modern World, ed. Londa Schiebinger and Claudia Swan (Philadelphia: University of Pennsylvania Press, 2005).

46 Catalogus, zbz, Dr O 456.4. On Clayton: Edmund Berkeley and Dorothy Smith Berkeley, John Clayton: Pioneer of American Botany (Chapel Hill: The University of North Carolina, 1963).

47 However, it was only in the first decades of the 19th century that botanical distribution maps were developed within a community of amateurs interested in applied botanical knowledge. Even then, they rather mapped cultivated than wild plants, as the former were easier to depict and of interest to a wider public. Nils Güttler, "Drawing the Line: Mapping Cultivated Plants and Seeing Nature in Nineteenth-Century Plant Geography," in New Perspectives on the History of Life Sciences and Agriculture, ed. Denise Phillips and Sharon Kingsland (Cham: Springer International Publishing, 2015), 29.

48 Gessner owned both editions (1738 and 1762). Catalogus, ZBZ, Dr O 456.4, 42 and 47.

49 Hortus siccus, vol. 1 for example, comprises species from the genera Circaea and Monarda. 
specimens collected by a specialist on Virginian flora. The Dutch botanist Jan Frederik Gronovius (1686-1762), whom he had met during his studies in Leiden, provided Gessner with plants that had been collected in Virginia by Clayton himself.

Gessner received many plants for the herbarium from Gronovius with notes connecting them to Virginia but to other places, too. Alongside a representative of the genus Ziziphora, for example, is noted "н в Gronovium" and next to the exemplar of Sclarea Mexicana L., a Salvia species, it is written "ex Herbario Gronov.," indicating that the specimens had been sent by Gessner's Dutch correspondent from his collection of dried plants. Gronovius also sent specimens from his garden, for example a representative of the genus Verbena..$^{50}$ The Dutch botanist had a plethora of plants from different corners of the world; and, obviously, he was eager to share them with his Swiss correspondent hoping to receive Alpine plants in return..$^{51}$ In his letters, Gronovius also shared information about the plants at his disposal, telling Gessner about his attempts to classify Clayton's specimens and his plans to publish Flora Virginica based on Clayton's findings. ${ }^{52}$ Hence, this direct contact to the publisher and the fact that he received dried specimens from this region encouraged Gessner's interest in Virginia's plant world and led to his familiarity with it.

The same applies to other regions recorded by Gessner as a particular "habitat". The case of Vera Cruz confirms the finding that familiarity with the flora of a certain territory was significantly enhanced by personal contacts with an explorer and the reception of plant material from there. ${ }^{53}$ Thus, for example, Boerhavia erecta in tableau VIII of the Tabulae phytographicae was labelled "Habitat in Vera Cruce." ${ }^{4}$ At the same time, Gessner obtained an exemplar of this species for his herbarium which he marked as "Collecta Vera Cruce a D. Houston," referring to the British physician William Houstoun (1695?-1733)

$50 \quad$ Hortus siccus, vol. 1.

51 For a more detailed study of the relations between Zurich and Dutch botanists, see Knittel, "Netzwerke der Botanik."

52 Letter, J. F. Gronovius to J. Gessner, 12 April 1738. zBZ, Ms. M 18.18.4.

53 Direct contacts with plant material also inspired Gessner's intensive involvement with the Siberian flora: Gessner made the acquaintance of Johann Georg Gmelin (1709-1755), who had explored that region during the Second Kamchatka Expedition between 1733 and 1743, when Gmelin visited Zurich in 1748. Subsequently, Gmelin became a supporter of the Physical Society's botanical garden and provided the botanists in Zurich with seeds and dried specimens for the herbarium, for example species belonging to the genera Salicornia and Blitum. Hortus siccus, vol. 1. For Gmelin's visit, see Boschung, Johannes Gessner, 96-98.

Tabulae phytographicae, 66 (Boerhavia erecta), 210-11 (Yucca aloifolia). 
who collected in Central America. ${ }^{55}$ In this case, too, the Dutch botanist Gronovius figured as a broker of specimens, inspiring Gessner's curiosity in the plant world of this far-away territory..$^{56}$ Subsequently, the study of the dried plants combined with the publications on their plant world, i.e. Flora Virginica and Reliquiae Houstonianae published by Joseph Banks (1743-1820) equipped the Zurich naturalist with specific knowledge of these regions he lacked for other ones. ${ }^{57}$ Through the specimens sent by his Dutch correspondent, the Zurich naturalist became familiar first-hand with plants from American territories like Virginia and Vera Cruz, which sparked his interest to learn more about them.

The case of the American plants proves that the Zurich naturalist's knowledge of plants from far-away territories was crucially influenced by the botanical collecting and studies of his Dutch and Swedish contemporaries. Plant material and publications from Leiden and Amsterdam, Stockholm, and Uppsala shaped Gessner's perception of the world's flora. Together, these examples show that it was the result of two factors: first, access to published literature pertaining to a given (and often not clearly defined) region; second, the ability to interact with collectors who had more privileged or first-hand access to plant materials from these regions than the botanist residing in the European hinterland.

\section{3}

\section{Puzzling over the Inaccessible}

The importance of the two factors identified in the previous section cannot be understood simply by studying far-away regions for which Gessner eventually succeeded in developing a nuanced understanding. In fact, it is even better illustrated by regions for which he failed to do so, where one of the factors was clearly lacking. Namely, the herbarium Gessner put together for the Zurich Physical Society, included four hundred plants declared to be "African" and perceived as something special by his contemporaries as well as later generations. ${ }^{58}$ Gessner had bought them from the estate of another collector,

\footnotetext{
55 Hortus siccus, vol. 1.

56 Letter, J. F. Gronovius to J. Gessner, 20 February 1734. zBz, Hss., Autogr Ott, Gronovius; Letter, J. Gessner to J.-F. Séguier, Zürich, 31 July 1752. Bibliothèque municipale de Nîmes, ms 498.14.

57 Catalogus, zBz, Dr O 456.4, 43 .

$5^{8}$ This number is given by Ferdinand Rudio in his 1896 publication. Ferdinand Rudio, "Festschrift der Naturforschenden Gesellschaft in Zürich; 1746-1896," Vierteljahrsschrift der Naturforschenden Gesellschaft in Zürich 41 (1896).
} 
who had picked them up around the Cape of Good Hope. While posing an enormous challenge to the Zurich naturalist, this collection of African plants offers an informative insight on the difficulties in his learning about the flora of far-away regions.

In 1753, with the help of his correspondents, Gessner managed to buy the collection of the recently deceased physician Laurent Garcin (1683-1752) from (then Prussian) Neuchâtel. As a young man, Garcin had travelled via the Cape of Good Hope to India, Java, Sumatra and Ceylon as a surgeon in the service of the Dutch East India Company (voc). ${ }^{59}$ The collection of dried plants he assembled during this journey gained some reputation in the following decades and by the time of his death had become a valuable good. Having been told about it by his correspondent Abraham Gagnebin (1707-180o), Gessner had cast an eye on the collection for some time, and wanted to obtain some specimens. ${ }^{60}$ Additionally, the Zurich naturalist had learned about Garcin's findings from the memoirs published in the Philosophical Transactions of the Royal Society and Johannes Burmann's Thesaurus Zeylanicus, which he held in his library. ${ }^{61}$ Thus, he knew that Garcin's collection consisted of hundreds of species from the Cape of Good Hope and the Indies, including some rare pieces.

After Garcin's death, Gessner rushed to buy the collection without first ascertaining its condition. As his correspondents acted fast, he was successful in buying the material he wished. Unfortunately, it proved difficult to make use of this acquisition. Not only had the dried specimens been shaken during the transport, but they also arrived in Zurich without labels. ${ }^{62}$ Subsequently, Gessner tried to obtain written information on the newly acquired specimens For weeks, he pushed his correspondent Samuel Engel (1702-1784) to put

59 The plants he had collected during this journey were described by Nicolaas Laurens Burman (1734-1793) in his Flora Indica (Amsterdam 1768). For the Indian plants of Garcin, see Alexandra Cook, "Laurent Garcin, M.D. F.R.S: A Forgotten Source for N. L. Burman's Flora Indica (1768)," Harvard Papers in Botany 21, no. 1 (2016).

6o Letter, A. Gagnebin to J. Gessner, 27 August 1749. ZBz, Autogr Ott, Gagnebin. On Gagnebin: Baldi, "Circulation."

61 Laurent Garcin, II. Memoirs communicated by Mons. Garcin to Mons. St. Hyacinthe, F.R.S. [...], in Philosophical Transactions 36 (1730); Garcin, "The Settling of a new Genus of Plants, called after the Malayans, MANGOSTANS," Philosophical Transactions 38 (1733). Johannes Burman, Thesaurus Zeylanicus (Amstelaedami: Apud Janssonio-Waesbergios, \& Salomonem Schouten, 1737). The posthumously published auction catalogue of Gessner's library proves ownership: ZBZ, Dr O456.4, 129 ; 41.

62 Letter, S. Engel to J. Gessner, 21 April 1753. ZBz, Hss., Ms. M 18.28.3. 
pressure on his contacts close to Garcin's heirs to send more information. ${ }^{63}$ Gessner hoped that there were notes in the estate that would enable him to learn what kind of plants exactly he had bought and where they came from. However, over time it became clear that hope was in vain and Garcin had never named the plants in his collection.

Consequently, identifying the plants proved extremely difficult: not only because the Cape of Good Hope, where Garcin had collected the specimens, remained inaccessible to Gessner, but also because printed material on those regions was limited and difficult to obtain. A botanist striving to identify material like this had to have contacts that would supply him with the publications and be able to afford the often-expensive prints. ${ }^{64}$ In the following decades, Gessner took on that task and never stopped purchasing new publications on the region where Garcin had collected, for example the Descriptiones plantarum ex capite Bonae Spei by Peter Jonas Bergius (1730-179o) comprising engravings of the South African flora. ${ }^{65}$ Despite all his efforts to expand his knowledge of the plant world of these far-away regions, Gessner did not succeed. All he could do was to classify parts of the dried specimens from Garcin's collection, while many have remained unidentified. For those plants he could not sort according to the Linnaean taxonomy, Gessner created a separate herbarium volume entitled Plantae vagae, relinquishing his ambitions to classify them. Hence, although many European travellers botanised around the Cape of Good Hope, the information he could accumulate in Zurich was not enough for Gessner to classify the specimens purchased from Garcin's estate. Some of the specimens were in an extremely poor state; for others the Zurich naturalist probably found no description in the publications he had access to. As Gessner could neither travel to the region nor query the collector or anybody

63 Correspondence with Samuel Engel in July 1753: Letter, S. Engel to J. Gessner, 2 July 1753. ZBZ, Hss., Ms. M 18.28.8; Letter, S. Engel to J. Gessner, 12 July 1753. ZBZ, Hss., Ms. M 18.28.9. For details of the discussion see Knittel, "Netzwerke der Botanik."

64 This is also expressed by the young Jakob Christoph Ramspeck (1722-1797) from Basel, who only saw the learned Albrecht von Haller capable of identifying the plants collected by Garcin. While the young Ramspeck obviously wanted to flatter the reputable naturalist Haller with this statement, it reveals that knowledge on these still little-known African plants remained reserved to botanists well equipped with books and correspondents. Letter, J. Ch. Ramspeck to A. von Haller, 8 January 1754. Boschung, Johannes Gessner, 105 .

65 Nicolaas Laurens Burman, Flora Indica: cui accedit series zoophytorum Indicorum, nec non prodromus florae Capensis (Amsterdam, 1768); Peter Jonas Bergius, Descriptiones plantarum ex capite Bonae Spei: cum differentiis specificis, nominibus trivialibus, et synonymis auctorum justis: secundum systema sexuale / ex autopsia concinnavit atque solicite digessit Petrus Jonas Bergius (Stockholm, 1767). Catalogus, zBZ, Dr O 456, 41 and 46. 
else familiar with the plants of the Cape of Good Hope about the localities, they remained "vague" to him.

The difficulties Gessner encountered with the specimens acquired were not a unique, individual problem. In fact, European naturalists had for centuries struggled to properly annotate collected specimens. Written instructions existed on how to gather and preserve plant specimens, requiring the specification of each object's provenance. ${ }^{66}$ In his Instructions, the English naturalist John Woodward (1665-1728) asked collectors to write on the outside of the quires of brown paper designed to contain the specimens: "in what Country the inclosed Collection of Plants were gathered." Additionally, he recommended a spatial separation of the specimens of different countries so that, should the markings get lost, the grouping of samples would reference their common provenance. ${ }^{67}$ While still on site, the collectors would map the plants in a way that was comprehensible to their readers and visitors, predominantly unfamiliar with the collecting sites. In his book Collecting the World, James Delbourgo has shown that, in many cases, names of plantations or of their owners, ports and trading posts were used as reference points, en passant employing a colonial order that subsequently affected the perception of the island's plant world. ${ }^{68}$

Together, these examples show that European botanists' knowledge about the flora of distant territories they could not visit in person depended on their ability to request details from those who assembled the herbarium collection. The mere availability of dried specimens as well as access to the growing body of literature on their regions of origin were not sufficient for that. Rather, the possibility of bringing specimens like "Garcin's African plants" together with book knowledge available in Europe strongly depended on each collector's diligence in recording at the scene.

66 For a history of these instructions in different political contexts, see the contribution of Simona Boscani Leoni in this volume. Especially collectors in Europe that invested money into the gathering of naturalia sought to enhance their chances of receiving well-preserved specimens enriched with as much information as possible, For the instructions of naturalists from London, see Mark Laird and Karen Bridgman, "American Roots: Techniques of Plant Transportation and Cultivation in the Early Atlantic World," in Ways of Making and Knowing: The Material Culture of Empirical Knowledge, ed. Pamela H. Smith, Amy Meyers, and Harold Cook (Ann Arbor: University of Michigan Press, 2014); Charles E. Jarvis, "Take with You a Small Spudd or Trowell': James Petiver's Directions for Collecting Natural Curiosities," in Naturalists in the Field, ed. Arthur MacGregor, (Leiden: Brill, 2018).

67 John Woodward, Brief Instructions for Making Observations in All Parts of the World: As also for Collecting, Preserving, and Sending over Natural Things (London: Printed for Richard Wilkin, 1696), 12.

68 James Delbourgo, Collecting the World: The Life and Curiosity of Hans Sloane (London: Allen Lane, 2017), 101. 
Based on the example of Johannes Gessner in Zurich, this contribution has focused on the factors influencing the plant knowledge accumulated by 18thcentury naturalists working away from botanical centres such as university towns and port cities. As shown, the Zurich botanist not only was an expert in local Swiss plants, especially those growing in mountainous areas of the eastern cantons, but he also had a more profound knowledge of plants from some far-away territories. The analysis revealed that three factors in particular were crucial in determining which territories he succeeded in developing a detailed understanding of.

First, the large number of books and journals he accumulated in his library shows that Gessner was a wealthy botanist with a working correspondence network. Hence, although he conducted his work away from a large botanical centre, he managed to keep pace with the emerging plant knowledge outside his home ground. However, this applies mainly to publications available in languages he easily understood, more specifically treatises in Latin as well as German translations of accounts originally published in vernaculars such as Swedish and English. Furthermore, Gessner's knowledge of the habitats of specific plants such as Cinchona or passionflowers was facilitated by his contemporaries' intensive concern with them. Their therapeutic benefit or their visually appealing flowers made these plants relatively well-studied objects. Consequently, botanists in Zurich and elsewhere could learn about their distribution, though they had only limited access to them.

Second, Gessner's more detailed study of plants from certain regions was prompted by the supply of dried specimens gathered by experts on the spot. This helped him gain a first-hand understanding of a territory`s otherwise unknown flora. However, the impact of these dried specimens on Gessner's knowledge was not limited to these same species. Rather, the study of the dried specimens encouraged him to purchase any new publications on these areas, which in turn would help him further consolidate his knowledge of these regions' flora more generally.

Third and most importantly, we have shown that it is precisely the interplay of these two factors that enabled Gessner to develop knowledge of a specific region. Knowledge of plants from distant territories remained rudimentary as long as written information was missing and available plant exemplars provided inadequate comparison with published species. The case of the herbarium specimens purchased from Garcin demonstrated that only scattered exemplars were identified and matched to flora of the Cape. So, the bulk of the 
plants remained only very vaguely associated with Africa. And yet Gessner had access to a growing literature on the Cape region.

Because he depended on both - namely accessible literature and access to dried specimens from a given region - Gessner's 'botanical world map' was far from universal. Rather, he had an extremely specific but in no way unusual perspective on the plants of far-away regions. The Zurich botanist saw them through Dutch-Swedish glasses, or more accurately binoculars. For knowledge in print on the flora of distant regions he drew mainly on publications authored in Dutch and Swedish university towns, whether in their original Latin version or in German translation. More exactly, the bulk of the publications Gessner used originated in a Linnaean context, i.e. they were published by early adopters and supporters of the system, or were written by students of Linnaeus and as such followed a particular pattern. At the same time, much of this plant knowledge on far-away territories was generated within the sphere of influence of the Dutch colonial trading companies. In conclusion, by using this knowledge, the Zurich botanist contributed to the universalisation of a specific perception of territories and their flora.

\section{Acknowledgements}

This contribution is based on research funded by the Swiss National Science Foundation and carried out in the context of the project "Kulturen der Naturforschung" (Cultures of Natural History), Project-Nr. 144731, led by Simona Boscani Leoni at the University of Bern (2014-2018).

\section{Bibliography}

\section{Manuscripts}

University of Zurich (UZH), Department of Systematic and Evolutionary Botany

Hortus siccus Societatis Physicae Tigurinae, collectus et Linnaeana methodo dispositus a Joanne Gesnero, 1751.

\section{Zentralbibliothek Zürich, Handschriftensammlung}

Autogr Ott, Gagnebin. Letter, A. Gagnebin to J. Gessner, 27 August 1749.

Autogr Ott, Gronovius. Letter, J. F. Gronovius to J. Gessner, 20 February 1734.

Ms. M 18.10. Autobiography J. Gessner.

Ms. M 18.18. Correspondence of J. F. Gronovius with J. Gessner. 
Ms. M 18.25. Correspondence of J.-F. Séguier with J. Gessner.

Ms. M 18.28. Correspondence of S. Engel with J. Gessner.

Ms. Z VIII 12. Repertorium J. Gessner.

Bibliothèque municipale de Nîmes

Ms 498.14 Letter, J. Gessner to J.-F. Séguier, Zürich, 31.07.1752.

Staatsarchiv Zürich (StAZ)

B IX 181 Tagbuch der Naturforschenden Gesellschaft Zürich, 3.

\section{Printed Sources}

Andreae, Johann Gerhart Reinhart. Briefe aus der Schweiz nach Hannover geschrieben in dem Jare 1763, 2. Abdruck. Zurich, Winterthur: Heinrich Steiner und Comp. Buchhändlern, 1776.

Anonymus [Salomon. Schinz], Catalogus Horti Botanici Societatis Physicae Turicensis, Zurich $1776 / 72$.

Burman, Johannes. Thesaurus Zeylanicus, exhibens Plantas in Insula Zeylana nascentes [...], Amstelaedami: Apud Janssonio-Waesbergios, \& Salomonem Schouten, 1737.

Catalogus. ZBz, Rare Book Department, Dr O 456.4 (Johann Füssli \& Son, Catalogus Librorum Bibliothecae Joannis Gessneri [...], Zurich 1798).

Garcin, Laurent. "II. Memoirs communicated by Mons. Garcin to Mons. St. Hyacinthe, F.R.S." Philosophical Transactions 36 (1730), 377-94.

Garcin, Laurent. "The Settling of a new Genus of Plants, called after the Malayans, MANGOSTANS." Philosophical Transactions 38 (1733): 232-242.

Hallman, Johan Gustaf. "Passiflora." In Amoenitates Academicae 1, Holmiae et Lipsiae: Apud Godofredum Kiesewette, 1749.

Kästner, Abraham Gotthelf. Der Königl. Schwedischen Akademie der Wissenschaften neue Abhandlungen aus der Naturlehre, Haushaltungskunst und Mechanik; auf das Jahr 1741. Leipzig, Hamburg: Heinsius,1750.

Linnaeus, Carl. Species plantarum: exhibentes plantas rite cognitas, ad genera relatas, cum differentiis specificis, nominibus trivialibus, synonymis selectis, locis natalibus, secundum systema sexuale digestas, Holmiae: Impensis Laurentii Salvii, 1753.

Rahn, Johann Heinrich et al. "Bemerkungen von der Würkung der Fieberrinde in verschiedenen Krankheiten." Abhandlungen der Naturforschenden Gesellschaft in Zürich 1 (1760): 189-210.

Schinz, Christoph Salomon. Johannis Gessneri Tabulae phytographicae, analysin generum plantarum exhibentes cum commentatione edidit Christ. Sal. Schinz. Zurich: Fuessli, 1795-1804.

Triewald, Mårten. "Anmerkungen über die Pflanzung ausländischer Frucht- und anderer Bäume in Schweden aus eigener Prüfung und Versuch vorgestellt von 
Martin Friedwald, Königl. Mechanico und Fortificationscapitain.” Der Königl. Schwedischen Akademie der Wissenschaften neue Abhandlungen aus der Naturlehre, Haushaltungskunst und Mechanik, auf das Jahr 1739, Leipzig, Hamburg: Heinsius, 1749: 250-54.

Triewald, Mårten. "Ein glücklich abgelaufener Versuch, ob die Glycyrrhiza oder das spanische Süßholz in Schweden wachse, und unsern Winter aushalten kann.” Der Königl. Schwedischen Akademie der Wissenschaften neue Abhandlungen aus der Naturlehre, Haushaltungskunst und Mechanik, auf das Jahr 1744, Hamburg, Leipzig: Heinsius, 1751: 226-3o.

Woodward, John. Brief Instructions for Making Observations in All Parts of the World: As also for Collecting, Preserving, and Sending over Natural Things. London: Printed for Richard Wilkin, 1696.

\section{Literature}

Baldi, Rossella. "La circulation du savoir botanique par le texte et par l'image: le 'Species plantarum' d'Abraham Gagnebin." In Rousseau Botaniste: Je vais devenir plante moimême, edited by Claire Jaquier and Timothée Léchot, 15-24. Fleurier: Editions du Belvédère, 2012.

Batsaki, Yota, Anatole Tchikine, and Sarah Burke Cahalan, eds. The Botany of Empire in the Long Eighteenth Century. Baltimore: Dumbarton Oaks Publishing, 2017.

Baumgartner, Sarah. "Das nützliche Wissen: Akteure, Tätigkeiten, Kommunikationspraxis und Themen der Naturforschenden Gesellschaft in Zürich, 1746 bis ca. 1830" (PhD diss., University of Bern, 2019).

Beretta, Marco, and Alessandro Tosi, eds. Linnaeus in Italy: The Spread of a Revolution in Science. Sagamore Beach: Science History Publications, 2007.

Berkeley, Edmund, and Dorothy S. Berkeley. John Clayton: Pioneer of American Botany. Chapel Hill: The University of North Carolina, 1963.

Boscani Leoni, Simona. "Men of Exchange: Creation and Circulation of Knowledge in the Swiss Republics of the Eighteenth Century." In Scholars in Action: The Practice of Knowledge and the Figure of the Savant in the 18th Century, edited by André Holenstein, Hubert Steinke, and Martin Stuber, 507-33. Leiden: Brill, 2013.

Boschung, Urs. Johannes Gessner (1709-1790): Der Gründer der Naturforschenden Gesellschaft in Zürich; Seine Autobiographie - aus seinem Briefwechsel mit Albrecht von Haller; Ein Beitrag zur Geschichte der Naturwissenschaften in Zürich im 18. Jahrhundert. Alpnach-Dorf: KOPRINT AG, 1995.

Bruijn, Iris. Ship's Surgeons of the Dutch East India Company: Commerce and the Progress of Medicine in the Eighteenth Century. Leiden: Leiden University Press, 2009.

Cook, Alexandra. "Laurent Garcin, M.D. F.R.S: A Forgotten Source for N. L. Burman's Flora Indica (1768)." Harvard Papers in Botany 21, no. 1 (2016): 31-53. 
Cooper, Alix. Inventing the Indigenous: Local Knowledge and Natural History in Early Modern Europe. Cambridge, New York: Cambridge University Press, 2007.

Delbourgo, James. Collecting the World: The Life and Curiosity of Hans Sloane. London: Allen Lane, 2017.

Egmond, Florike, Esther van Gelder, and Nicolas Robin, eds. Flowers of Passion and Distinction: Practice, Expertise and Identity in Clusius' World. Stuttgart: Franz Steiner Verlag, 2012.

Frodin, David G., Guide to Standard Floras of the World. Cambridge, New York: Cambridge University Press 2001.

Gänger, Stefanie. A Singular Remedy: Cinchona Across the Atlantic World, 1751-1820. Cambridge, New York: Cambridge University Press, 2020.

Gaziello, Catherine. L'expédition de Lapérouse 1785-1788: réplique française aux voyages de Cook. Paris: CTHS, 1984.

Güttler, Nils. "Drawing the Line: Mapping Cultivated Plants and Seeing Nature in Nineteenth-Century Plant Geography." In New Perspectives on the History of Life Sciences and Agriculture, edited by Denise Phillips and Sharon Kingsland, 27-52. Cham: Springer International Publishing, 2015.

Heller, Sabine. Boerhaaves Schweizer Studenten: Ein Beitrag zur Geschichte des Medizinstudiums. Zurich: Juris-Verlag, 1984.

Hodacs, Hanna. "Linnaean Scholars Out of Doors: So Much to Name, Learn and Profit From." In Naturalists in the Field: Collecting, Recording and Preserving the Natural World from the Fifteenth to the Twenty-First Century, edited by Arthur MacGregor, 240-57. Leiden: Brill, 2018.

Jarvis, Charles E. “'Take with you a small Spudd or Trowell': James Petiver's Directions for Collecting Natural Curiosities." In Naturalists in the Field: Collecting, Recording and Preserving the Natural World from the Fifteenth to the Twenty-First Century, edited by Arthur MacGregor, 212-39. Leiden: Brill, 2018.

Knittel, Meike. "Netzwerke der Botanik: Johannes Gessner (1709-179o) und die botanische Forschung im 18. Jahrhundert" (PhD diss., University of Bern, 2018).

Knittel, Meike and Reto Nyffeler. "Flora Alpina." In Montan-Welten: Alpengeschichte abseits des Pfades, edited by Tina Asmussen. Æther o3. Zürich: intercom Verlag, 2019. Last modified: May 2019. https://aether.ethz.ch/ausgabe/montan-welten/ flora-alpina/, accessed on 26 April 2021.

Knittel, Meike. "Dominus Creavit Ex Terra Medicamenta': Heilpflanzenwissen in Johannes Gessners Phytographia sacra." In Wer das Gras wachsen hört: Wissensgeschichte(n) der pflanzlichen Ressourcen vom Mittelalter bis ins 20.Jahrhundert, edited by Simona Boscani Leoni and Martin Stuber. Jahrbuch für Geschichte des ländlichen Raumes 14. Innsbruck: Studien-Verlag, 2017.

Knittel, Meike. "Devenir botaniste au XVIIIe siècle: les premiers voyages de Gessner et des jeunes Zurichois dans les Alpes." Bulletin de l'Association culturelle pour le voyage en Suisse 20, 2019: 5-9. 
Laird, Mark and Karen Bridgman. "American Roots: Techniques of Plant Transportation and Cultivation in the Early Atlantic World." In Ways of Making and Knowing: The Material Culture of Empirical Knowledge, edited by Pamela H. Smith, Amy Meyers and Harold Cook, 164-93. Ann Arbor: University of Michigan Press, 2014.

Leu, Urs, ed. Natura Sacra: Der Frühaufklärer Johann Jakob Scheuchzer (1672-1733). Zug: Achius Verlag, 2012.

Leu, Urs. “Konrad Gessner und die Neue Welt." Gesnerus 49, 3-4 (1992): 279-309.

Lienhard, Luc. "La machine botanique': Zur Entstehung von Hallers Flora der Schweiz," in Hallers Netz: Ein europäischer Gelehrtenbriefwechsel zur Zeit der Aufklärung, edited by Martin Stuber, Stefan Hächler and Luc Lienhard, 371-41o. Basel: Schwabe, 2005 .

Marti, Hanspeter. "Leiden." Historisches Lexikon der Schweiz Online. Last modified November 20, 2008. https://hls-dhs-dss.ch/de/articles/oo6615/2008-11-20/, accessed on 30 April 2021.

Miller, David P. and Peter H. Reill, eds. Visions of Empire: Voyages, Botany and Representations of Nature. Cambridge, New York: Cambridge University Press, 1996. Müller-Wille, Staffan. "Walnuts at Hudson Bay, Coral Reefs in Gotland:The Colonialism of Linnean Botany." In Colonial Botany: Science, Commerce, and Politics in the Early Modern World, edited by Londa Schiebinger and Claudia Swan, 34-48. Philadelphia: University of Pennsylvania Press, 2005.

Nieto, Mauricio. "Presentación gráfica, desplazamiento y aprobación de la naturaleza en las expediciones botánicas del siglo XVIII," Asclepio 47, no. 2 (1995): 91-107.

Önnerfors, Andreas. "Auswärtige Saamen und Gewächse ingleichen zur Correspondence: Die Verbreitung Linnéscher Naturalhistorie in Schwedisch-Pommern im 18. Jahrhundert," in Wissen im Netz: Botanik und Pflanzentransfer in europäischen Korrespondenznetzen des 18. Jahrhunderts, edited by Regina Dauser, Stefan Hächler, Michael Kempe, Franz Mauelshagen and Martin Stuber, 91-111. Berlin: AkademieVerlag, 2008.

Oscarsson, Ingemar. “... who has had the courage and ambition to learn Swedish': The Handlingar of the Swedish Academy of Sciences in 18th Century European Translations, Adaptations, and Reviews." La Révolution française 13 (2018): 1-23. doi:10.400o/lrf.1910, accessed 20 April 2021.

Pardo-Tomás, José. "Two Glimpses of America from a Distance: Carolus Clusius and Nicolás Monardes." In Carolus Clusius: Towards a Cultural History of a Renaissance Naturalist, edited by Florike Egmond, P. G. Hoftijzer and Robert P. W. Visser, 173-94. Amsterdam: Koninklijke Nederlandse Akademie van Wetenschappen, 2007.

Puig-Samper, Miguel A. "Difusión e institucionalización del sistema linneano en España y América." in Mundializacion de la ciencia y cultura nacional: Actas del congreso international "Ciencia, Descubrimento y Mundo Colonial," edited by Antonio Lafuente, Alberto Elena and María Luísa Ortega, 349-59. Aranjuez: Doce Calles, 1993 . 
Rudio, Ferdinand. "Festschrift der Naturforschenden Gesellschaft in Zürich; 17461896." Vierteljahrsschrift der Naturforschenden Gesellschaft in Zürich 41 (1896).

Schär, Bernhard C. Tropenliebe: Schweizer Naturforscher und niederländischer Imperialismus in Südostasien um 19oo. Frankfurt am Main: Campus Verlag, 2015.

Schlunegger, Ernst. "Allamand, Frédéric-Louis." Historisches Lexikon der Schweiz Online. Last modified April 26, 2021. https://hls-dhs-dss.ch/de/articles/o43932/ 2021-04-26/, accessed on 30 April 2021.

Sigerist, Henry E. Albrecht von Haller's Briefe an Johannes Gesner (1728-1777). Berlin: Weidmann, 1923.

Stearn, William T. "The Influence of Leyden on Botany in the Seventeenth and Eighteenth Century." The British Journal for the History of Science 1, no. 2 (1962): 137-58.

Zangger, Andreas. Koloniale Schweiz: Ein Stück Globalgeschichte zwischen Europa und Südostasien (1860-1930). Bielefeld: transcript, 2011. 